\title{
Imaging features that allow for the recognition of Menkes disease
}

\author{
Características de imagem que permitem reconhecer a doença de Menkes \\ José Iram Mendonça do Rego ${ }^{1}$, Antonio Jose da Rocha ${ }^{2}$, Vanderley Segatelli ${ }^{3}$, Ebe Christie de Oliveira ${ }^{3}$
}

Menkes disease (MD) is an infantile-onset, X-linked recessive neurodegenerative disorder (ATP7A gene on chromosome Xq21.1) in which copper transport and connective tissue arrangement is disturbed ${ }^{1}$. Variable MD phenotypes are strictly related to abnormal collagen and elastin formation that are more due to the lysyloxidase deficiency, which results in skin and hair alterations associated with tortuous and elongated intracranial vessels, in addition to bladder diverticula and bony abnormalities ${ }^{1,2,3}$.

When imaging suggests $\mathrm{MD}$, laboratory results are used to confirm the diagnosis (Figure). Genetic counseling and early treatment with daily copper injections is suggested to improve outcomes for this rare disease $e^{2,3,4}$.
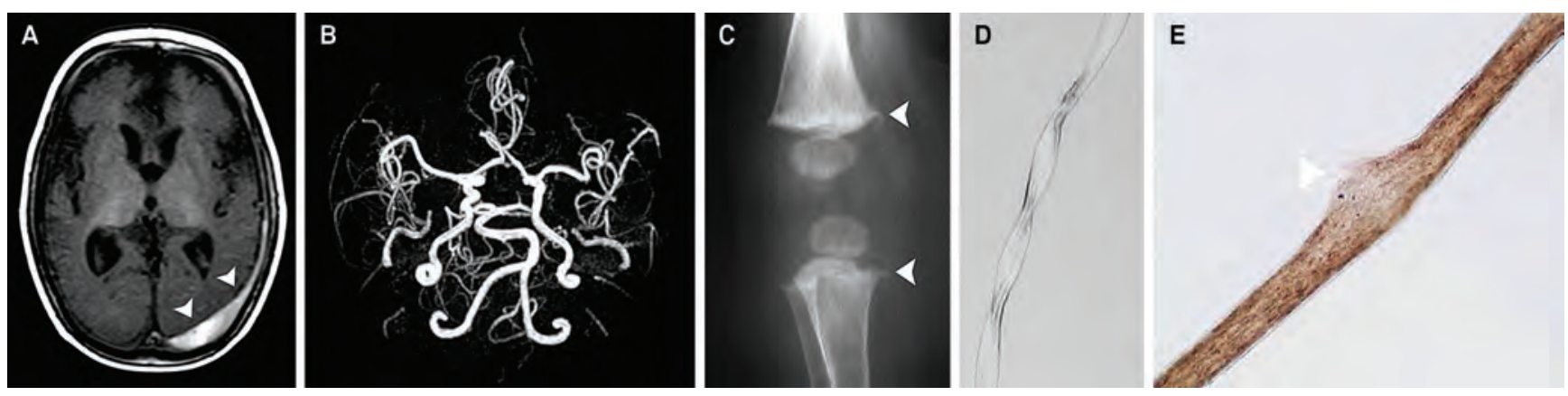

Figure. A 9-month-old boy presented with hypotonia, seizures, developmental delay, failure to thrive and hypopigmented skin and hair (copper=99.8 ug/dL ( $183-152 \mathrm{ug} / \mathrm{dL}$ ) and ceruloplasmin=4 mg/dL (20-60 mg/dL)). Axial T1WI (A) showed brain atrophy associated to left parietal subdural hemorrhage (arrowhead). Kinking and coiling of the intracranial vessels were depicted on MR angiography (B). Plain radiograph (frontal view) of the left lower limb (C) showed femoral and tibial metaphyseal spurs (arrowhead). In scalp hairs, regularly spaced twists compatible with pili torti (D) and nodes of trichorrhexis-nodosa (E) were also observed (arrowhead).

\section{References}

1. Kim BE, Petris MJ. Phenotypic diversity of menkes disease in mottled mice is associated with defects in localisation and trafficking of the atp7a protein. J Med Genet 2007;44:641-646.

2. Cosimo QC, Daniela L, Elsa B, Carlo DV, Giuseppe F. Kinky hair, kinky vessels, and bladder diverticula in menkes disease. J Neuroimag 2011;21:e114-116.
3. Amador E, Domene R, Fuentes C, Carreno JC, Enriquez G. Longterm skeletal findings in menkes disease. Pediatric Radiol 2010;40:1426-1429.

4. Arita JH, Faria EC, Peruchi MM, Lin J, Rodrigues Masruha M, Vilanova LC. Menkes disease as a differential diagnosis of child abuse. Arq Neuropsiquiatr 2009;67:507-509.

\footnotetext{
'Divisão de Neurologia e Neurocirurgia, Hospital Regional de Pariquera-açu, Sao Paulo SP, Brazil;

${ }^{2}$ Divisão de Neurorradiologia, Santa Casa de Misericórdia de São Paulo, Sao Paulo SP, Brazil;

${ }^{3}$ Divisão de Patologia, Hospital Israelita Albert Einstein, Sao Paulo SP, Brazil.

Correspondence: Antonio Jose da Rocha; Santa Casa de Misericórdia de São Paulo, Serviço de Diagnóstico por Imagem: Rua Dr. Cesário Motta Junior, 112 Vila Buarque; 01221-020 Sao Paulo SP, Brasil; E-mail: a.rocha@uol.com.br

Conflict of interest: There is no conflict of interest to declare.

Received 16 January 2014; Received in final form 13 February 2014; Accepted 05 March 2014.
} 